\title{
Factors that Influence the Uptake of Breast Cancer Screening among Secondary School Student: Case of Kisii South Sub-County Kenya
}

Thomas Orindi Ondimu*, Fred A Amimo, Peter Sumba Odado and Ben Sereta

Jaramogi Oginga Odinga University of Science and Technology, Nairobi, Kenya

\begin{abstract}
Breast cancer kills about 40,000 women annually across the globe. Worldwide there is rise in new case of breast cancer; most of these cases are reported in developing countries. In Africa breast cancer is characterized by presentation with the advanced disease, inadequate information about breast cancer's incidence and inaccessibility of facilities significant for screening purposes. In Kenya, most cases of breast cancer are presented with stage 3 and 4 of the disease. It is important to examine the establishment of breast health education in the curriculum and school setting, the level of breast screening awareness, accessibility of screening facilities and the role socio-economic, demographic and cultural beliefs, students' attitude and fear of the uptake breast cancer screening. The aim of this study was to analyze the factors that affect the uptake of breast self examination among students in secondary schools in Kisii south sub-county. Health belief model formed the basis for this study and data was collected using interviews administered through questionnaires. The study targeted secondary school students of ages 13-22 years randomly sampled from 147 students. The schools from the sub-county were systematically sampled and data obtained was analyzed using both descriptive and inferential statistics. Descriptive statistics include frequency chart and table while inferential statistics include Pearson's chi-square $\left(\mathrm{X}^{2}\right)$ and correlation analysis. The statistical package for social science, SPSS, was used for computer statistical analysis. $75.5 \%$ of the respondents had never undertaken any form of breast screening. The research found significant association between SECD, psychological factors, institutional factors and student levels of knowledge about breast cancer with breast cancer screening uptake. Students with a lower social economic status were found to be less likely to undertake screening services. The study findings will help the ministries of Health and Education to formulate policies that are directed at promotion of early breast health seeking behaviour among the students.
\end{abstract}

\section{Keywords: Cancer; Screening; Stigma}

\section{Background}

Breast cancer kills about 40,000 women annually across the globe [1] thus being the primary cancer cause among women. Over 1.2 million females are diagnosed with by breast cancer on annual basis globally. There is a varying rate within the international with a range of between 3.9 individuals against 100,000 in Mozambique and 101.1 in the United States [1]. 16.6-29.9 cases per 100,000 persons. These low rates have been attributed to low screening rates and incomplete reporting. Breast cancer cases in Africa are characteristic of; high cost of screening, presentation with the advanced disease, inadequate information about breast cancer incidence, and inaccessibility of facilities significant for the screening purposes [2]. Between 2010 and 2012, this was the mainly diagnosed form of cancer amongst Kenyan women with about $80 \%-90 \%$ of the presented cases with stage 3 and 4 of the ailment, when treatment cost is high with low survival chances [3]. One out of every nine Kenyan tested positive with breast cancer at its advanced levels [4]. Majority Kenyan women start the diagnosis of breast cancer just as a death penalty, delaying their health seeking behaviour. The belief that breast cancer is incurable necessitates delay as other options that are culturally acceptable are excavated in tandem with the edifying characterization of the disease [5]. The emergence of breast disease and the subsequent development of cancer tend to be more aggressive in young women compared with breast cancer progression in the older population [6]. Young women aged 20-29 years with breast cancer experienced mortality rate of $72.4 \%$ from the diseases. The high mortality rate among young women mainly due to lack of breast cancer awareness [6]. Early detection of breast cancer plays an important role in reducing its morbidity and mortality. Breast self-examination (BSE), mammography, and clinical breast examination (CBE) are considered as screening methods for early detection of breast cancer [7]. Although, there is debate surrounding the efficacy of routine BSE in early detection of breast cancer [8]. BSE is still an important screening tool for early detection of breast cancer in developing countries, because it is cheap, widely available, and does not require complex technical training [8]. Overall, practicing BSE could provide an opportunity for women to know how their breasts normally feel and able to notice any changes in their breast tissue [9]. This complements the breast health awareness education and supplements women with knowledge on what to do when a lump is detected. Despite the relative benefits of BSE, its application remains low [10]. Studies conducted among women in Bushehr, a city in south of Iran, showed that only $41.9 \%$ had performed BSE in the past and $7.6 \%$ of them performed it regularly. Similar results were found among Malaysian female, which showed only $36.7 \%$ conducting BSE practice. In a recent research, young Malaysian female were noted not know how to perform a BSE [11]. In some, a lack of awareness regarding the necessity of regular BSE has an impact on the engagement of this screening practice i [7]. Therefore, understanding the student's beliefs regarding BSE can be used to design appropriate educational interventions to promote this screening behavior [12]. According to a research report by the Kenya Medical Research Institute (KEMRI), in the year 2006, barely 2 out of 87 hospitals within Nyanza could provide expert breast screening services, suggestive of inaccessibility principally

*Corresponding author: Thomas Orindi Ondimu, Jaramogi Oginga Odinga University of Science and Technology, Nairobi, Kenya, Tel: +254 513637; E-mail: thomexas@yahoo.com

Received: December 21, 2015; Accepted: January 22, 2016; Published: January 26 2016

Citation: Ondimu TO, Amimo FA, Odado PS, Sereta B (2016) Factors that Influence the Uptake of Breast Cancer Screening among Secondary School Student: Case of Kisii South Sub-County Kenya. Oncol Cancer Case Rep 1: 109.

Copyright: (C) 2016 Ondimu TO, et al. This is an open-access article distributed under the terms of the Creative Commons Attribution License, which permits unrestricted use, distribution, and reproduction in any medium, provided the original author and source are credited. 
to the country populous. Very limited laboratories have the required equipment for undertaking the breast cancer research [13] and the current infrastructure in cancer management that is unable to handle all recently diagnosed cases. Based on a report by [14], schools are excellent points of contact for young people to acquire knowledge and attitudes. Moreover, they are receptive to information in school compared to any other environment, hence the need to explore the role of schools in promoting breast cancer screening [15] proposed that, school health promotion should provide curricula to empower teenagers with competency in taking reproductive health actions and that screening be undertaken by qualified health personnel. The ministry of health $(\mathrm{MOH})$-gave recommendations on the establishment of youth friendly services in existing education facilities to promote their reproductive health [16]. Many factors however are bound to affect breast health awareness, breast self-examination (BSE) and screening among secondary school students. It, therefore, becomes necessary to acquire information on the different factors that discourage screening among students, their allocation and how significant they are in the decision making process in the participation of breast cancer screening.

\section{Statement of the Problem and Justification}

Globally, there is a rise in the incidences of breast cancer and this is more prominent in the developing nations. The rising breast cancer incidence rate in Kenya is a major concern in the women's health, yet little research has been done to impede the rise. The number of females referred from Kisii level 5 hospital to Kenyatta National hospital for specialized levels of cancer screening, diagnosis and the successive treatment raised from 54 in the year 2012 to 96 in 2013 which translated to approximately $78 \%$ increment. About $32 \%$ of the cases that had been referred were presented with stage 3 and 4 of the disease. This increase in incidence, high mortality and presentation with advanced cases of breast cancer raised gaps associated to the level of awareness of breast cancer, BSE and screening among the adolescents in the county, considering that BSE alone greatly decreases the incidence of late cancer presentation [3]. Culture and religion are major determinants of health behavior [5], yet perspectives of students regarding breast cancer haven't been widely studied. Though secondary schools are excellent agents for the socialization of the youth into responsible reproductive health, there was reluctance in adoption of Breast Health Education (BHE) in secondary schools and very little deliberate effort had been made to reach the students. If the factors affecting BSE and clinical screening among students were not investigated, it would impede equity in access to healthcare among vulnerable girls in secondary schools hence increase the incidence and mortality associated to late breast cancer reporting. It would also be impracticable to understand the various factors that discouraged or encouraged participation of the youth in BSE and clinical screening for which there is little information.

\section{Methodology}

\section{Research design}

This study used cross sectional survey research design. This design was preferred in to obtain diverse information about the students' attitudes, opinions and habits related to breast screening uptake using questionnaires and interviews. It was also flexible, easy to administer and cheaper in data collection. In this study, information about the factors that influence early screening for breast cancer among secondary school students was sought from students and teachers using questionnaires and interviews respectively, supplemented by secondary data sources which included; the secondary school syllabus, ministerial policy frameworks and the WHO school health policy framework. This data was processed to provide descriptive data.

\section{Variables}

The dependent variable was the uptake of breast screening for breast cancer, whereas the independent variables was; the secondary school curriculum and setting, distance to screening facilities, SECDs, attitude, perceptions and feelings about breast cancer, BSE and breast cancer screening.

\section{Study area}

This study was carried out in, Kisii south sub-county Kenya. It is located on latitude $0.6^{\circ}$ and longitude $34.75^{\circ}$. See map attached (appendix II). All the 15 secondary schools within the sub-county were identified and included in the study.

\section{Study population}

The target population was the secondary school students in Kisii south sub-county. All the students aged 13-22 years in the selected schools were targeted. The study area had an estimated secondary school student population of 7100 . See attached list of secondary schools within the study region (appendix III).

\section{Sampling procedure}

Schools: All secondary schools in the sub-county were identified and included in the cross sectional survey research to provide a larger and more representative sample.

Students: The students were picked from each secondary school by simple random sampling and proportionately (to the entire student population in the sub-county) until the desired sample Size was attained. This guaranteed that extra students were picked from schools with more students. Equally, the proportionate percentage of students in each form was used to determine the participants within each school. Simple random numbers were assigned to all students from class registers and using the Table of random numbers the students were selected for inclusion in the study until the desired percentage was found in each form and school respectively.

Sample size: This was determined by using Fisher's formula

$\mathrm{n}=\mathrm{Z}^{2} \mathrm{pq}^{\mathrm{D}} / \mathrm{d}^{2}$

Whereby; $\mathrm{n}$ the preferred sample size (if the target population is greater than 10,000$)$

\section{$\mathrm{Z}=$ he standard normal deviate 1.96 at $95 \%$ confidence interval}

$\mathrm{P}=$ estimated prevalence of breast cancer in the population,

0.11 (Neondo, 2006)

$\mathrm{q}=1-\mathrm{p}=0.89$

$\mathrm{d}=$ level of statistical significance set at 0.05 .

$\mathrm{D}=$ design effect $=1$ and therefore;

$$
\mathrm{n}=\frac{1.96^{2} \times 0.11 \times 0.89}{(0.05)^{2}}=150
$$

Since the target population was less than 10,000 , the final sample estimate $\left(\mathrm{n}_{\mathrm{f}}\right)$ was calculated using the formula:

$\mathrm{n}_{\mathrm{f}}=\frac{n}{1}+\frac{n}{N}$

Where: 
$\mathrm{n}_{\mathrm{f}}=$ the desired sample size (when the population is less than 10,000)

$\mathrm{n}=$ the preferred sample size (when the population is greater than $10,000)$

$\mathrm{N}=$ the estimate of the population size, hence;

$$
\mathrm{n}_{\mathrm{f}}=\frac{150}{1+150 / 7100}=147
$$

Therefore the minimum sample size to be obtained was 147 students picked randomly and proportionately from each of the schools.

\section{Construction of research instruments}

Structured and open ended questionnaires to be used in the study were constructed from the objectives of the study. This ensured that each item related to a specific objective. Considerations were made for how information obtained from each item was to be analyzed. The items were concise, in a logical sequence and with adequate information. Some items were to be rated on the Likert scale.

\section{Pilot study}

The questionnaire were pretested in 3 of the 12 randomly selected secondary schools in Kitutu chache south sub-county whose sample was similar to the actual sample. The questionnaires were self-administered and participants were encouraged to make suggestions about the instructions, clarity of questions and relevance.

\section{Validity and reliability}

Validity: The validity of the questionnaire was based on expert opinion and a field test. The supervisors and a panel of experts examined the questionnaire and the appropriate changes they recommended on; content, construct, criterion and face validity will be made in consideration of the field test results.

Reliability: A pilot test was carried out involving at least 30 respondents not included in the actual sample to obtain data that was analyzed by SPSS to determine the reliability coefficient. Furthermore, the split-half technique was utilized in assessing the reliability of the questionnaire.

\section{Data collection and analysis}

Data collection: Sources of data were both primary and secondary. Secondary data was obtained by analyzing the K.I.E Syllabus to examine extent of the integration of Breast Health Education in the secondary curriculum. Primary data was collected using pretested structured and open-ended questionnaires. Interviews were used to get in accurate data. The type of data to be gathered included; awareness and practice of B.S.E and breast cancer screening, Level of establishment of B.H.E in the curriculum and school setting, role of socio-economic, cultural and demographic factors, role of fear and attitude in the uptake of BSE and breast screening uptake.

Data analysis: The data collected was analyzed using the statistical package for social sciences (SPSS). Frequency charts and proportions were used to compare the student's responses to B.S.E and breast cancer screening uptake. Chi square coupled with correlation analysis were used to determine the association between; Level of breast cancer, BSE and screening awareness with uptake of screening curriculum, school setting and breast health education with BSE and screening uptake. Access to screening facilities with screening uptake, SECDs with students' uptake of BSE and breast screening and the relationship that do exist between the variables themselves Students' attitude and fear on uptake of BSE and breast cancer screening. In analyzing secondary data, the total number of subtopics that cover to any extent B.H.E was identified from the syllabus and policy statements and then percentages were used to find out how frequent B.H.E and screening were presented to students in the secondary curriculum and school settings.

Ethical and logistical considerations: Permission to carry out the study was sought from the board of post graduate of JOOUST and the University of Eastern Africa Baraton Ethical Review committee also from Kisii teaching and referral hospital, further clearance was sought from Kisii south sub county education officer. Information consent from the respondent was sought by adequate the objective was studied and completed consent form. Informed consent from the respondents was sought by informing them the objectives of the study and completing consent form. The respondents were assured of confidentiality with all the information that they provided in the questionnaire.

\section{Results and Discussion}

\section{Introduction}

This chapter presents the characteristics of the respondents, the main results obtained from the result analyses of the research findings discussion and conclusions.

\section{Results}

Gender of respondents: Table 1 gives the frequency of the gender of the individuals who turned out for the interview which can be clearly illustrated by Figure 1 of a pie-chart showing the proportion of male and female respondents during the process of data collection in various schools within the sub-county of Kisii south. Clearly the number of male students stood at $52 \%$ which surpasses the $48 \%$ of their female counterparts. This low number of female students can be attributed to the alleged male chauvinism in the region which only sees the male child as the viable creature to be educated as opposed to women whose roles are meant to sit at home and wait for time to come so as to be married.

The source of information about breast examination and screening: Out of the 147 respondents, 67 conquered to have heard of the existence of the breast cancer screening either within the subcounty or outside the county a number which in percentage form translates to $45.6 \%$. This number raised the curiosity about the source of information for breast cancer screening (Table 2). This information, as illustrated in Figure 2, radio at 29.25\% turned out to be the major source

\begin{tabular}{|c|c|c|c|c|c|}
\hline \multicolumn{5}{|c|}{ Respondents gender } \\
\hline \multirow{3}{*}{ Valid } & Female & 71 & 48.3 & 48.3 & 48.3 \\
\cline { 2 - 6 } & Male & 76 & 51.7 & 51.7 & 100.0 \\
\cline { 2 - 6 } & Total & 147 & 100.0 & 100.0 & \\
\hline
\end{tabular}

Table 1: Respondents
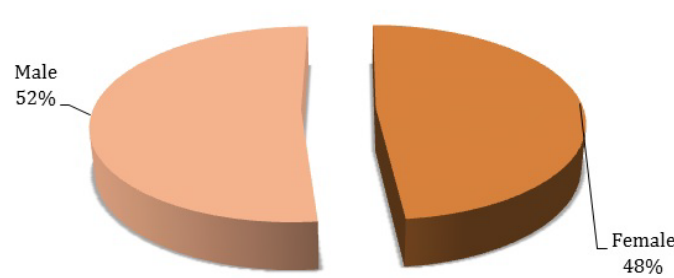

Figure 1: Gender of respondent. 
Citation: Ondimu TO, Amimo FA, Odado PS, Sereta B (2016) Factors that Influence the Uptake of Breast Cancer Screening among Secondary School Student: Case of Kisii South Sub-County Kenya. Oncol Cancer Case Rep 1: 109.

Page 4 of 9

of information within the region owing to its outstanding advantages such as one being able to tune into the station of their choice and to the language which they are well acquainted to. This was surprisingly closely followed by internet at $27.89 \%$. It is quite surprising as everyone wouldn't have wished internet to have come before television. However it is vital to embrace the fact that technology has come up so fast such that a lot of affordable internet enabled phones are readily available in the market together with the low costs of acquiring data bundles among the renowned mobile service providers such as Safaricom, Orange and Airtel. The last in the list is Nurse/Doctors who at $4.76 \%$ are rarely seen prior to booking appointments and even if one had to see them

\begin{tabular}{|c|c|c|c|c|c|}
\hline \multirow{2}{*}{ Valid } & Frequency & Percent & $\begin{array}{c}\text { Valid } \\
\text { Percent }\end{array}$ & $\begin{array}{c}\text { Cumulative } \\
\text { Percent }\end{array}$ \\
\hline \multirow{3}{*}{} & Yes & 67 & 45.6 & 45.6 & 45.6 \\
\cline { 2 - 6 } & No & 80 & 54.4 & 54.4 & 100.0 \\
\cline { 2 - 6 } & Total & $\mathbf{1 4 7}$ & $\mathbf{1 0 0 . 0}$ & $\mathbf{1 0 0 . 0}$ & \\
\hline
\end{tabular}

Table 2: Have you ever heard of breast cancer screening?

Source of information about breast cancer screening

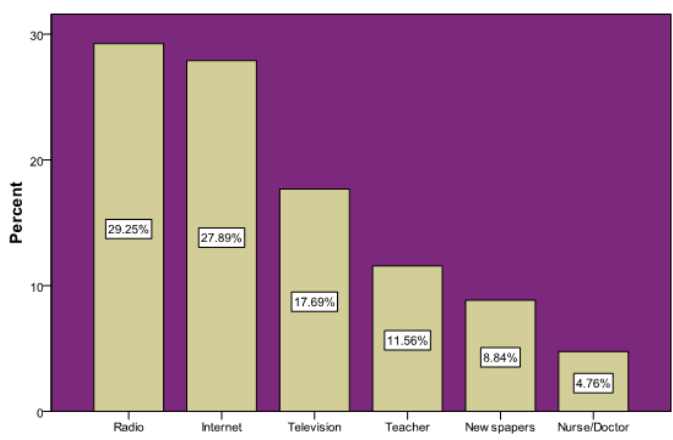

Figure 2: Source of information about breast cancer screening.

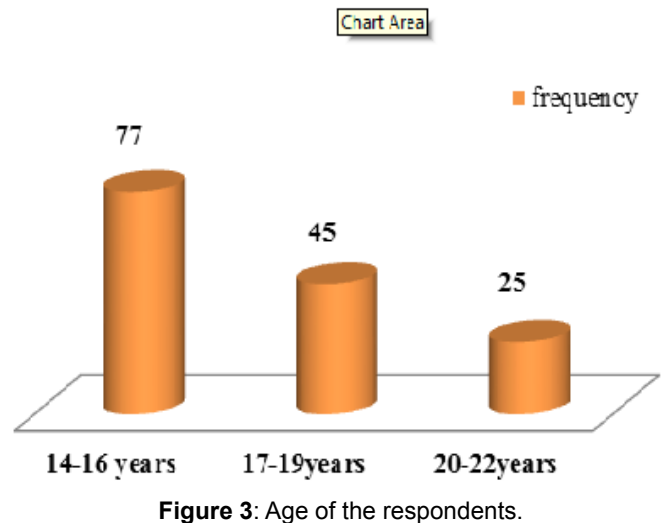

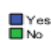

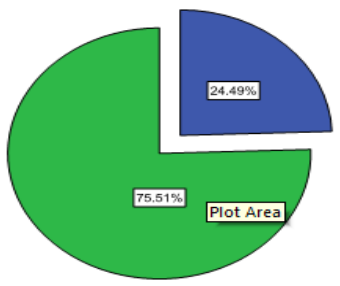

Figure 4: Have you ever carried self-breast examination

\begin{tabular}{|c|c|c|c|c|c|}
\hline & & Frequency & Percent & $\begin{array}{c}\text { Valid } \\
\text { Percent }\end{array}$ & $\begin{array}{c}\text { Cumulative } \\
\text { Percent }\end{array}$ \\
\hline \multirow{4}{*}{ Valid } & Excellent & 16 & 10.9 & 44.4 & 44.4 \\
\hline & Good & 16 & 10.9 & 44.4 & 88.9 \\
\hline & Fair & 4 & 2.7 & 11.1 & 100.0 \\
\hline & Total & 36 & 24.5 & 100.0 & \\
\hline Missing & System & 111 & 75.5 & & \\
\hline \multicolumn{2}{|c|}{ Total } & 147 & 100.0 & & \\
\hline
\end{tabular}

Table 3: Ability to do self-breast examination.

$$
\text { Yes } \quad \text { No }
$$
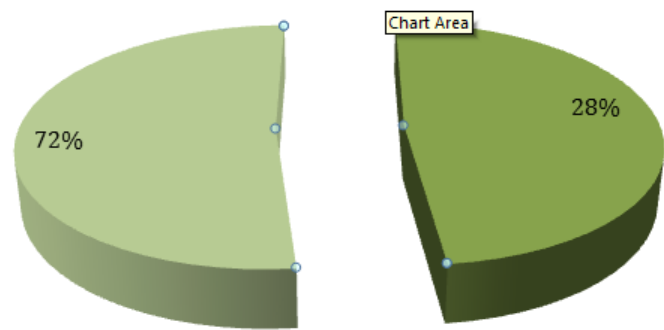

Figure 5: Uptake of clinical breast examination/screening.

a consultation fee has to be paid as always the case which to me draws the needy at bay from accessing the necessary information from them. It surprises me and even the reader that only $11.56 \%$ of this information is accessed from the teachers who are always in constant contact with the students from the region. This mean one thing the education curriculum has put less emphasis on this menacing disease amongst many other factors to be addressed in later in the chapter.

The age of the respondents: Figure 3 illustrates the age groups of the respondents, majority being those ones falling between the age group $14-16$ years at $52.4 \%$ followed by the ones aged between $17-19$ years at $30.6 \%$ and lastly at $17 \%$ are those ones aged between $20-22$ years.

Uptake of self-breast screening examination: From Figure 4 one can clearly see that very few have ever thought of carrying out or rather have carried out self-breast examination reasons coming out clearly towards the end of this analysis. Out of those who managed to carry out self-breast examination a greater percentage had the ability to do so without any problem as seen from Table 3.

Clinical breast examination/screening: Majority of the respondents confirmed to have not taken breast screening/examination in the clinics within the region. $72 \%$ of them confirmed to have not done so either by self-examination or availing themselves to be examined or screened at the clinics within the region as shown in Figure 5.

Educational sessions about breast health and screening: Most of the times that health officers/nurses do organize breast health and screening educational sessions, majority of the students only attended once as exhibited in Figure 6, above owing to the fact that may be the don't always see the relevance of doing so or rather poor of channel of communication within the school or still this can be attributed to location of the school from the health facility among other factors.

Secondary school curriculum on breast self-examination and breast screening: Rarely do students learn about breast selfexamination and breast screening in the secondary school curriculum as highlighted by the high frequency in the Figure 7 above may be 
Citation: Ondimu TO, Amimo FA, Odado PS, Sereta B (2016) Factors that Influence the Uptake of Breast Cancer Screening among Secondary School Student: Case of Kisii South Sub-County Kenya. Oncol Cancer Case Rep 1: 109.

Page 5 of 9

because the curriculum developers never taken into account the issue of breast-self-examination and screening as a matter of great importance to the students at still a tender age.

Training/seminars on breast self-examination and breast screening: Other factors held constant majority would expect that most of individuals to attend a training/seminar on breast self-examination and breast cancer screening given a chance at the moment. However this would not be the case as about $67.3 \%$ of the respondents still opted not to avail themselves should such an opportunity present itself as illustrated in the Table 4.

Curable of breast cancer: Something to smile about is that at least $58.5 \%$ of the respondents are aware that early breast cancer is curable as summarised in Table 5. However majority still are not well acquainted with the consequences of presenting themselves with advanced breast cancer as illustrated in Table 6.

\section{Influence of institutional factor on breast cancer screening uptake}

A table of correlation above highlights on the extent and nature

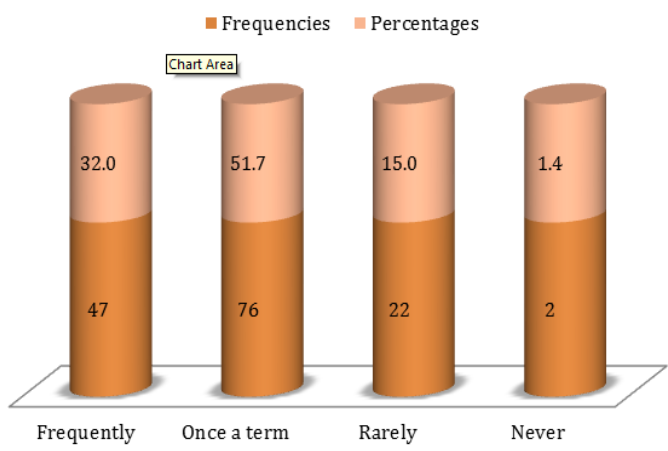

Figure 6: Frequency of educational sessions about breast health and screening organized by health officers/nurses.

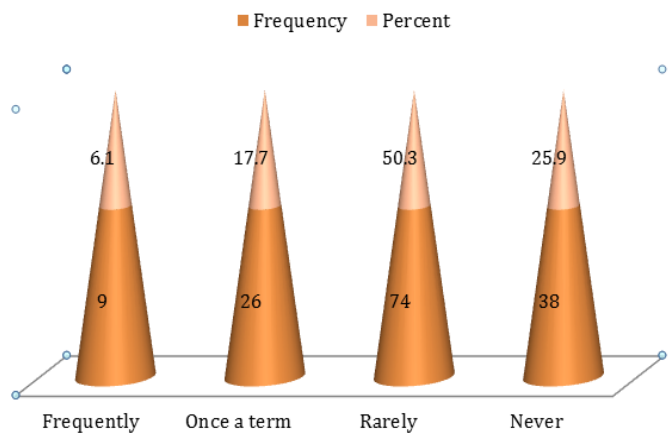

Figure 7: How often do you learn about breast self-examination and breast screening in the secondary school curriculum?

\begin{tabular}{|c|c|c|c|c|c|}
\hline & & Frequency & Percent & $\begin{array}{c}\text { Valid } \\
\text { Percent }\end{array}$ & $\begin{array}{c}\text { Cumulative } \\
\text { Percent }\end{array}$ \\
\hline \multirow{2}{*}{ Valid } & Yes & 48 & 32.7 & 32.7 & 32.7 \\
\cline { 2 - 6 } & No & 99 & 67.3 & 67.3 & 100.0 \\
\cline { 2 - 6 } & Total & $\mathbf{1 4 7}$ & $\mathbf{1 0 0 . 0}$ & $\mathbf{1 0 0 . 0}$ & \\
\hline
\end{tabular}

Table 4: Would you attend a training/ seminar on breast self-examination and breast cancer screening if you were given a chance now?

\begin{tabular}{|c|c|c|c|c|c|}
\hline & & Frequency & Percent & Valid Percent & $\begin{array}{c}\text { Cumulative } \\
\text { Percent }\end{array}$ \\
\hline \multirow{2}{*}{ Valid } & Yes & 86 & 58.5 & 58.5 & 58.5 \\
\cline { 2 - 6 } & No & 61 & 41.5 & 41.5 & 100.0 \\
\cline { 2 - 6 } & Total & $\mathbf{1 4 7}$ & $\mathbf{1 0 0 . 0}$ & $\mathbf{1 0 0 . 0}$ & \\
\hline
\end{tabular}

Table 5: Early breast cancer is curable.

\begin{tabular}{|c|c|c|c|c|c|}
\hline & & Frequency & Percent & Valid Percent & $\begin{array}{c}\text { Cumulative } \\
\text { Percent }\end{array}$ \\
\hline \multirow{2}{*}{ Valid } & Yes & 48 & 32.7 & 32.7 & 32.7 \\
\cline { 2 - 6 } & No & 99 & 67.3 & 67.3 & 100.0 \\
\cline { 2 - 6 } & Total & $\mathbf{1 4 7}$ & $\mathbf{1 0 0 . 0}$ & $\mathbf{1 0 0 . 0}$ & \\
\hline
\end{tabular}

Table 6: Aware of consequences of presenting with advanced breast cancer.

\begin{tabular}{|c|c|c|c|c|}
\hline \multicolumn{5}{|c|}{ Correlations } \\
\hline & & $\begin{array}{l}\text { Have you } \\
\text { ever gone } \\
\text { for clinical } \\
\text { breast } \\
\text { screening? }\end{array}$ & $\begin{array}{l}\text { Proximity of } \\
\text { breast cancer } \\
\text { screening } \\
\text { facilities from } \\
\text { home/school }\end{array}$ & $\begin{array}{l}\text { What is } \\
\text { the cost of } \\
\text { breast cancer } \\
\text { screening and } \\
\text { clinical breast } \\
\text { examination } \\
\text { in the hospital } \\
\text { facilities? }\end{array}$ \\
\hline \multirow{3}{*}{$\begin{array}{l}\text { Have you ever gone } \\
\text { for clinical breast } \\
\text { screening? }\end{array}$} & $\begin{array}{l}\text { Pearson } \\
\text { Correlation }\end{array}$ & 1 & 0.032 & 0.152 \\
\hline & $\begin{array}{c}\text { Sig. } \\
\text { (2-tailed) }\end{array}$ & & 0.698 & 0.067 \\
\hline & $\mathrm{N}$ & 147 & 147 & 147 \\
\hline \multirow{3}{*}{$\begin{array}{l}\text { Proximity of breast } \\
\text { cancer screening } \\
\text { facilities from home/ } \\
\text { school }\end{array}$} & $\begin{array}{l}\text { Pearson } \\
\text { Correlation }\end{array}$ & 0.032 & 1 & 0.097 \\
\hline & $\begin{array}{c}\text { Sig. } \\
\text { (2-tailed) }\end{array}$ & 0.002 & & 0.021 \\
\hline & $\mathrm{N}$ & 147 & 147 & 147 \\
\hline \multirow{3}{*}{$\begin{array}{l}\text { What is the cost } \\
\text { of breast cancer } \\
\text { screening and } \\
\text { clinical breast } \\
\text { examination in the } \\
\text { hospital facilities? }\end{array}$} & $\begin{array}{l}\text { Pearson } \\
\text { Correlation }\end{array}$ & 0.152 & 0.097 & 1 \\
\hline & $\begin{array}{c}\text { Sig. } \\
\text { (2-tailed) }\end{array}$ & 0.006 & 0.043 & \\
\hline & $\mathrm{N}$ & 147 & 147 & 147 \\
\hline
\end{tabular}

Table 7: Correlation on uptake of clinical breast screening and institutional factors.

of the relationship that exists between the dependent variable which is the uptake of breast screening and other variables of interest. It can be clearly observed from Table 7 above that both dependent variable and the variables proximity of the health facilities from home or school and cost of breast cancer screening is positively correlated with all the values lying with the accepted region of -1 and 1 . This is further confirmed by their respective levels of significance which are well below the 0.05 set probability value. Predictors: Proximity of the health facility from home/school, Media used for advertisement and Education on relevance of breast screening in control of cancer. Both Tables 8 and 9 emphasizes on the significance of our model with all the variables, which can be termed as institutional factors being significant as 0.031 is less than the accepted probability value of 0.05 . This in essence confirms that the uptake of breast cancer screening being our dependent variable is influenced by the above named institutional factors. Virtually each variable describes a $2.4 \%$ variation of the dependent variable as shown under the column of R square in Table 8. Each factor's influence on the dependent variable is explained by the beta values in the table of coefficient below. The Standardized beta coefficients column in Table 10 
Citation: Ondimu TO, Amimo FA, Odado PS, Sereta B (2016) Factors that Influence the Uptake of Breast Cancer Screening among Secondary School Student: Case of Kisii South Sub-County Kenya. Oncol Cancer Case Rep 1: 109.

Page 6 of 9

\begin{tabular}{|c|c|c|c|c|}
\hline Model & $\mathbf{R}$ & $\mathbf{R}$ Square & $\begin{array}{c}\text { Adjusted R } \\
\text { Square }\end{array}$ & $\begin{array}{c}\text { Std. Error of the } \\
\text { Estimate }\end{array}$ \\
\hline 1 & 0.154 & 0.024 & 0.003 & 0.501 \\
\hline \multicolumn{4}{|c|}{ Table 8: Model summary } \\
\hline
\end{tabular}

Table 8: Model summary.

\begin{tabular}{|c|c|c|c|c|c|c|}
\hline \multicolumn{2}{|c|}{ Model } & $\begin{array}{c}\text { Sum of } \\
\text { Squares }\end{array}$ & df & Mean Square & F & Sig. \\
\hline \multirow{2}{*}{1} & Regression & 0.865 & 3 & 0.288 & 1.150 & 0.031 \\
\cline { 2 - 7 } & Residual & 35.842 & 143 & .251 & & \\
\cline { 2 - 7 } & Total & $\mathbf{3 6 . 7 0 7}$ & $\mathbf{1 4 6}$ & & \\
\hline \multicolumn{5}{|c}{ Table 9: ANOVA. } \\
\hline
\end{tabular}

\begin{tabular}{|c|c|c|c|c|c|c|}
\hline \multicolumn{2}{|r|}{ Model } & \multicolumn{2}{|c|}{$\begin{array}{l}\text { Unstandardized } \\
\text { Coefficients }\end{array}$} & \multirow{2}{*}{$\begin{array}{c}\begin{array}{c}\text { Standardized } \\
\text { Coefficients }\end{array} \\
\text { Beta }\end{array}$} & \multirow[t]{2}{*}{$\mathbf{T}$} & \multirow[t]{2}{*}{ Sig. } \\
\hline & & B & Std. Error & & & \\
\hline \multirow{4}{*}{1} & (Constant) & 1.193 & 0.275 & & 4.334 & 0.000 \\
\hline & $\begin{array}{l}\text { Proximity of the } \\
\text { health facility }\end{array}$ & 0.241 & 0.067 & 0.020 & 0.236 & 0.013 \\
\hline & $\begin{array}{l}\text { Media used } \\
\text { to advertise } \\
\text { breast cancer } \\
\text { examination/ } \\
\text { screening }\end{array}$ & 0.051 & 0.050 & 0.034 & 1.815 & 0.002 \\
\hline & $\begin{array}{c}\text { Education on } \\
\text { relevance of } \\
\text { breast screening } \\
\text { in control of breast } \\
\text { cancer }\end{array}$ & 0.091 & 0.085 & 0.151 & -0.180 & 0.010 \\
\hline
\end{tabular}

Table 10: Dependent variable: Uptake of breast cancer screening.

\begin{tabular}{|c|c|c|c|}
\hline & Observed N & Expected N & Residual \\
\hline Agree & 71 & 36.8 & -29.8 \\
\hline Agree Strongly & 54 & 36.8 & -21.8 \\
\hline Disagree & 15 & 36.8 & 17.3 \\
\hline Disagree strongly & 7 & 36.8 & 34.3 \\
\hline Total & $\mathbf{1 4 7}$ & & \\
\hline
\end{tabular}

Table 11: Some religious beliefs may prevent students from carrying out breast examination and screening for breast cancer. explains the impact of each variable in determining the dependent variable. As one can see education explains about 15.1 percent of the dependent variable. This means that uptake of breast cancer is screening is much relevant to the educated than the less educated. Also of importance is the appreciation of media contribution towards uptake of breast screening as it explains about $3.4 \%$ of the dependent variable. Proximity which is also key affects $2 \%$ of the uptake of breast cancer screening.

Socio-economic, demographic and cultural influence on uptake of breast cancer screening/ examination among school respondents

There are significant associations between socio-economic and cultural factors on breast screening uptake respectively as exhibited by the outcome of the chi-square test carried on the relevant variables as shown in Table 11. Tables 12 and 13 exhibits the relationship that exists between the uptake of breast cancer screening and the socio-economic and cultural influence. A highly significant positive correlation occurs between the religious beliefs that prevent students from taking breast examination/screening of breast cancer and the uptake of clinical breast screening (Chi-square value $=76.973, \mathrm{df}=3, \mathrm{p}<0.05),(\mathrm{r}=0.152, \mathrm{p}=0.00)$ and out of $72 \%$ of the total respondents who did not undertake clinical breast examination, $85.03 \%$ attributed this to the existing religious beliefs in their respective communities (Tables 12 and 14). Socio-cultural factors have significant negative correlation with clinical breast examination (Chi-square value $=57.837, \mathrm{df}=2, \mathrm{p}<0.05),(\mathrm{r}=-0.52, \mathrm{p}=<0.05)$ and again another $85.03 \%$ of the total respondents did not undertake clinical breast screening due to socio-cultural factors (Tables 12 and 14). Clearly from the Table 15 , it is clear that BSE at a health facility is negatively significantly related to the breast screening examination and breast cancer uptake among the students who participated in the study. The reasons for this phenomenon are outlined in the chapter five of the study

\section{The influence of psychosocial factors on breast cancer screening uptake}

Table 15 presents psychosocial factors that influence breast cancer

\begin{tabular}{|c|c|c|c|c|c|}
\hline & & $\begin{array}{c}\text { Have you ever gone for } \\
\text { clinical breast examination/ } \\
\text { screening? }\end{array}$ & $\begin{array}{c}\text { Some Cultural beliefs and } \\
\text { practices in the community } \\
\text { may prevent students } \\
\text { from undertaking breast } \\
\text { examination and screening } \\
\text { for breast cancer }\end{array}$ & $\begin{array}{l}\text { Some religious beliefs may } \\
\text { prevent students from carrying } \\
\text { out breast examination and } \\
\text { screening for breast cancer }\end{array}$ & $\begin{array}{c}\text { The cost of breast } \\
\text { cancer screening may } \\
\text { prevent students from } \\
\text { going for early breast } \\
\text { cancer screening in } \\
\text { hospitals. }\end{array}$ \\
\hline \multirow{3}{*}{$\begin{array}{l}\text { Have you ever gone for } \\
\text { clinical breast examina- } \\
\text { tion/screening? }\end{array}$} & $\begin{array}{l}\text { Pearson Cor- } \\
\text { relation }\end{array}$ & 1 & -0.052 & 0.152 & 0.332 \\
\hline & Sig. (2-tailed) & & 0 & 0 & 0 \\
\hline & $\mathrm{N}$ & 147 & 147 & 147 & 147 \\
\hline $\begin{array}{l}\text { Some Cultural beliefs and } \\
\text { practices in the }\end{array}$ & $\begin{array}{l}\text { Pearson Cor- } \\
\text { relation }\end{array}$ & -0.052 & 1 & 0.056 & 0.026 \\
\hline \multirow[t]{2}{*}{$\begin{array}{l}\text { community may prevent } \\
\text { students from undertak- } \\
\text { ing breast examination } \\
\text { and screening for breast } \\
\text { cancer }\end{array}$} & sig. (2-tailed) & 0.533 & & 0.503 & 0.753 \\
\hline & $\mathrm{N}$ & 147 & 147 & 147 & 147 \\
\hline \multirow{3}{*}{$\begin{array}{l}\text { Some religious beliefs } \\
\text { may prevent students } \\
\text { from carrying out } \\
\text { breast examination and } \\
\text { screening for breast } \\
\text { cancer }\end{array}$} & $\begin{array}{l}\text { Pearson } \\
\text { Correlation }\end{array}$ & 0.152 & 0.056 & 1 & 0.106 \\
\hline & sig. (2-tailed) & 0 & 0 & & 0 \\
\hline & $\mathrm{N}$ & 147 & 147 & 147 & 147 \\
\hline \multirow{3}{*}{$\begin{array}{l}\text { The cost of breast cancer } \\
\text { screening may prevent } \\
\text { students from going } \\
\text { for early breast cancer } \\
\text { screening in hospitals. }\end{array}$} & $\begin{array}{l}\text { Pearson } \\
\text { Correlation }\end{array}$ & $0.332^{* *}$ & 0.026 & 0.106 & 1 \\
\hline & sig. (2-tailed) & 0 & 0 & 0 & \\
\hline & $\mathrm{N}$ & 147 & 147 & 147 & 147 \\
\hline
\end{tabular}

Table 12: Correlation on clinical breast examination/screening and socio-economic and culture influence. 
Citation: Ondimu TO, Amimo FA, Odado PS, Sereta B (2016) Factors that Influence the Uptake of Breast Cancer Screening among Secondary School Student: Case of Kisii South Sub-County Kenya. Oncol Cancer Case Rep 1: 109.

Page 7 of 9

screening uptake. Fear, Anxiety, embarrassment, social pressure and stigma are significantly associated to breast cancer screening uptake. There is significant association between fear, anxiety, Embarrassment and breast screening uptake (Chi square $=7.837$, df $2, \mathrm{p}<0.05)$ and $62.59 \%$ of the total respondents did not undertake breast screening examination due to the fear associated to finding breast cancer (Tables 15-8). Social pressure and stigma is highly associated to clinical breast screening uptake (Chi square value $=57.837, \mathrm{df}=2, \mathrm{p}<0.05$ ) and $62.59 \%$ of the total respondents who did not undertake breast screening attributed it to the social pressure and stigma associated to it (Tables 17 and 19). There is a significant relationship between uptake of breast screening examination, student commitment and imparting knowledge to the student to outsiders as opposed to their studies the more their chance of undertaking BSE uptake is reduced (Table 20). On the latter case student prefer to be addressed by stranger on matter that touches on their well being as opposed to their teachers something of which a

Some Cultural beliefs and practices in the community may prevent students from undertaking breast examination and screening for breast cancer

\begin{tabular}{|c|c|c|c|}
\hline & Observed N & Expected N & Residual \\
\hline Agree & 33 & 49.0 & -16.0 \\
\hline Strongly & 92 & 49.0 & 43.0 \\
\hline Disagree & 22 & 49.0 & -27.0 \\
\hline Total & 147 & & \\
\hline
\end{tabular}

Table 13: Cultural beliefs and practices that prevent student from undertaking breast examination and screening for breast cancer

\begin{tabular}{|c|c|c|}
\hline & \multicolumn{2}{|c|}{ Test Statistics } \\
\hline & $\begin{array}{c}\text { Cultural beliefs and practices in the } \\
\text { community }\end{array}$ & Religious beliefs \\
\hline Chi-Square & 57.837 & 76.973 \\
\hline Df & 2 & 3 \\
\hline Asymp. Sig. & 0.00 & 0.00 \\
\hline
\end{tabular}

Table 14: Test statistics.

\begin{tabular}{|c|c|c|c|}
\hline & & $\begin{array}{c}\text { Have you ever } \\
\text { gone for clinical } \\
\text { breast screening? }\end{array}$ & $\begin{array}{l}\text { Age of the } \\
\text { respondents }\end{array}$ \\
\hline \multirow{3}{*}{$\begin{array}{l}\text { Have you ever gone } \\
\text { for clinical breast } \\
\text { screening? }\end{array}$} & $\begin{array}{l}\text { Pearson } \\
\text { Correlation }\end{array}$ & 1 & -0.032 \\
\hline & Sig. (2-tailed) & & 0.08 \\
\hline & $N$ & 147 & 147 \\
\hline \multirow{3}{*}{ Age of the respondents } & $\begin{array}{l}\text { Pearson } \\
\text { Correlation }\end{array}$ & -0.032 & 1 \\
\hline & Sig. (2-tailed) & 0.002 & \\
\hline & $\mathrm{N}$ & 147 & 147 \\
\hline
\end{tabular}

Table 15: Correlations on BSE and age.

\begin{tabular}{|c|c|c|c|}
\hline & Observed N & Expected N & Residual \\
\hline Agree & 33 & 49.0 & -16.0 \\
\hline Agree Strongly & 92 & 49.0 & 43.0 \\
\hline Disagree & 22 & 49.0 & -27.0 \\
\hline Total & 147 & & \\
\hline
\end{tabular}

Table 16: Fear, Anxiety and Embarrassment prevent students from going for breast cancer screening.

\begin{tabular}{|c|c|c|c|}
\hline & Observed N & Expected N & Residual \\
\hline Agree & 33 & 49.0 & -16.0 \\
\hline Agree strongly & 92 & 49.0 & 43.0 \\
\hline Disagree & 22 & 49.0 & -27.0 \\
\hline Total & $\mathbf{1 4 7}$ & & \\
\hline
\end{tabular}

Table 17: Social pressure and stigma associated to breast cancer may prevent students from going for early breast cancer screening.

\begin{tabular}{|c|c|c|c|c|}
\hline & & $\begin{array}{l}\text { Have you } \\
\text { ever gone } \\
\text { for clinical } \\
\text { breast } \\
\text { examination/ } \\
\text { screening? }\end{array}$ & $\begin{array}{l}\text { Fear, Anxiety and } \\
\text { Embarrassment } \\
\text { prevent students } \\
\text { from going for } \\
\text { breast cancer } \\
\text { screening }\end{array}$ & $\begin{array}{l}\text { Social pressure and } \\
\text { stigma associated } \\
\text { to breast cancer } \\
\text { may prevent } \\
\text { students from going } \\
\text { for early breast } \\
\text { cancer screening }\end{array}$ \\
\hline \multirow{3}{*}{$\begin{array}{l}\text { Have you } \\
\text { ever gone for } \\
\text { clinical breast } \\
\text { examination/ } \\
\text { screening? }\end{array}$} & $\begin{array}{l}\text { Pearson } \\
\text { Correlation }\end{array}$ & 1 & -0.052 & -0.052 \\
\hline & $\begin{array}{c}\text { Sig. } \\
\text { (2-tailed) }\end{array}$ & & 0.533 & 0.533 \\
\hline & $\mathrm{N}$ & 147 & 147 & 147 \\
\hline \multirow{2}{*}{$\begin{array}{l}\text { Fear, Anxiety } \\
\text { and Embar- } \\
\text { rassment pre- } \\
\text { vent students } \\
\text { from going for } \\
\text { breast cancer } \\
\text { screening }\end{array}$} & $\begin{array}{l}\text { Pearson } \\
\text { Correlation }\end{array}$ & -0.052 & 1 & 1.000 \\
\hline & $\begin{array}{c}\text { Sig. } \\
\text { (2-tailed) }\end{array}$ & 0.533 & & .000 \\
\hline \multirow{3}{*}{$\begin{array}{l}\text { Fear, Anxiety } \\
\text { and Embar- } \\
\text { rassment pre- } \\
\text { vent students } \\
\text { from going for } \\
\text { breast cancer } \\
\text { screening }\end{array}$} & $\begin{array}{l}\text { Pearson } \\
\text { Correlation }\end{array}$ & -0.052 & 1 & 1.000 \\
\hline & $\begin{array}{c}\text { Sig. } \\
\text { (2-tailed) }\end{array}$ & 0.533 & & 0.000 \\
\hline & $\mathrm{N}$ & 147 & 147 & 147 \\
\hline \multirow{3}{*}{$\begin{array}{c}\text { Social } \\
\text { pressure } \\
\text { and stigma } \\
\text { associated to } \\
\text { breast cancer } \\
\text { may prevent } \\
\text { students from } \\
\text { going for early } \\
\text { breast cancer } \\
\text { screening }\end{array}$} & $\begin{array}{l}\text { Pearson } \\
\text { Correlation }\end{array}$ & -0.052 & 1.000 & 1 \\
\hline & $\begin{array}{c}\text { Sig. } \\
\text { (2-tailed) }\end{array}$ & 0.533 & .000 & \\
\hline & $\mathrm{N}$ & 147 & 147 & 147 \\
\hline
\end{tabular}

Table 18: Correlations on clinical breast examination/screening and psychosocial factors.

\begin{tabular}{|c|c|c|}
\hline & $\begin{array}{c}\text { Fear, Anxiety and } \\
\text { Embarrassment }\end{array}$ & $\begin{array}{c}\text { Social Pressure and } \\
\text { Stigma }\end{array}$ \\
\hline Chi-Square & 57.837 & 57.837 \\
\hline Df & 2 & 2 \\
\hline Asymp. Sig. & 0.000 & 0.000 \\
\hline
\end{tabular}

Table 19: Test Statistics.

time make them too shy off or even stop communicating their problems if there did exist any.

\section{Summary, Conclusions and Recommendations}

\section{Introduction}

The main focus of the study was to investigate on the factors that promote or discourage breast self-examination among secondary school students in Kisii South sub-county. The findings of the study will contribute some knowledge to stakeholders, policy makers on how to come up with more effective curriculum to promote/enhance impede the looming cases of breast cancer not only among the students in the county but also the entire country and to great extent the entire world. This chapter presents summary of the study and research findings as per the specific objectives of the study, conclusion and recommendations on the possible ways of addressing breast cancer. 


\section{Correlations}

\begin{tabular}{|c|c|c|c|c|}
\hline & & $\begin{array}{l}\text { Have you ever gone for clinical breast } \\
\text { examination/screening? }\end{array}$ & $\begin{array}{l}\text { Social and Educational Commitment } \\
\text { deny students enough time to } \\
\text { undertake early breast cancer } \\
\text { screening in specialized health } \\
\text { facilities. }\end{array}$ & $\begin{array}{l}\text { The teaching of breast health, Breast } \\
\text { self-examination and screening for } \\
\text { breast cancer should be carried out } \\
\text { by other professionals outside the } \\
\text { school rather than teachers. }\end{array}$ \\
\hline \multirow{3}{*}{$\begin{array}{l}\text { Have you ever gone for } \\
\text { clinical breast examination/ } \\
\text { screening? }\end{array}$} & Pearson Correlation & 1 & -0.152 & 0.001 \\
\hline & Sig. (2-tailed) & & 0.067 & 0.995 \\
\hline & $\mathrm{N}$ & 147 & 147 & 147 \\
\hline \multirow{3}{*}{$\begin{array}{l}\text { Social and Educational } \\
\text { Commitment deny students } \\
\text { enough time to undertake } \\
\text { early breast cancer screening } \\
\text { in specialized health facilities. }\end{array}$} & Pearson Correlation & -0.152 & 1 & 0.085 \\
\hline & Sig. (2-tailed) & .067 & & 0.303 \\
\hline & $\mathrm{N}$ & 147 & 147 & 147 \\
\hline \multirow{3}{*}{$\begin{array}{l}\text { The teaching of breast health, } \\
\text { Breast self-examination and } \\
\text { screening for breast cancer } \\
\text { should be carried out by other } \\
\text { professionals outside the } \\
\text { school rather than teachers. }\end{array}$} & Pearson Correlation & 0.001 & 0.085 & 1 \\
\hline & Sig. (2-tailed) & 0.995 & 0.303 & \\
\hline & $\mathrm{N}$ & 147 & 147 & 147 \\
\hline
\end{tabular}

Table 20: Correlations on clinical breast examination/screening and knowledge.

\section{Discussion of the findings}

The overall purpose of the study was to do an examination on the factors that promote or discourage breast self-examination and screening among secondary school students in Kisii south subcounty and come up with various proposals on how these factors can be improved to make sure that this menace is curbed. The specific objectives of the study were:

a. To examine the student's level of awareness about breast cancer, BSE, and Breast cancer screening.

b. To analyze the extent to which the secondary school curriculum and school setting address B.H.E (Breast Health Education), B.S.E and screening for breast cancer.

c. To explore the extent to which secondary school student's access screening facilities, undertake BSE and breast cancer screening.

d. To explore the role of socio-economic, cultural and demographic factors (SECDs), attitude, fear and embarrassment on the student's uptake of screening for breast cancer.

Students level of awareness about breast cancer, BSE and breast cancer screening: Most of the respondents precisely $54.4 \%$ were unaware of the existence of breast cancer, BSE and breast cancer screening. This can be attributed the factors that have already been mentioned in chapter four.

Institutional characteristics in breast screening uptake among students: Significant associations were found between: Breast health education at school and breast screening uptake, guidance and follow up by nurses on BSE and the uptake of screening, advertisement on breast cancer screening and the uptake of breast screening, and the respondents' knowledge concerning breast cancer screening and uptake of screening. Eighty nine point one percent of the respondents who did not undertake screening had low knowledge about breast cancer and the screening process and $85.4 \%$ of the students who did not undertake clinical breast examination had never been provided with breast health education either at a hospital facility or at school. Nurses or teachers had never guided Eighty eight percent of the students who did not undertake BSE on the necessity and agility of conducting BSE.

Psychosocial factors in breast cancer screening uptake: A significant association was found between: fear and breast screening uptake, the anticipated pain during a breast cancer screening uptake among the respondents, socio-stigma and clinical breast screening uptake, the concern that breast screening is embarrassing and the uptake of clinical breast examination. Thirty eight point seven percent of the respondents did not undertake BSE due to the fear associated to finding breast cancer, whereas $94.7 \%$ of the respondents held that the pain and discomfort associated to breast cancer screening was a deterrent to its uptake, especially among students. Only $26.4 \%$ of the respondents held that embarrassment inhibits breast-screening uptake.

Cultural and religious practices in breast screening uptake among the students: There is significant association between cultural practices and breast screening uptake among the respondents. Religious practices and clinical breast screening uptake have significant positive association. Ninety two point eight percent of the respondents who undertook clinical breast examination held that some cultural practices may influence breast screening uptake.

Socio-economic and cultural factors in breast cancer screening uptake: There is significant association between; travel distance to the screening facility and clinical breast screening uptake, the cost of screening and the uptake of clinical breast screening, Commitments and the uptake of clinical breast examination among the respondents. $41.9 \%$ of the respondents did not undertake breast screening due to the long distance to screening facilities, whereas $47.3 \%$ of the respondents did not undertake clinical breast examination due to the high cost of screening. In addition, there was a significant association between; the socio-economic status of the respondents and breast screening uptake, Socio-cultural factors and clinical breast examination, educational level of the respondents and breast screening uptake. $36 \%$ of the respondents who did not undertake breast screening attributed it to the socio-stigma associated to breast cancer.

Demographic factors: Demographic factors such as age and travel distances and travel distance to breast screening uptake were found to be significantly associated to breast screening uptake among students. There is actually a negative association between age and clinical screening uptake. From the descriptive analysis done on age illustrated in Figure 3, the respondents within the age bracket of 14-16 years had the highest uptake while the respondents in the age bracket 2022 years had the least uptake of breast screening uptake considerably the least breast feeding hence breast screening uptake considerably decreases with increase in age an aspect which can be attributed to loss 
of keenness about breast health on assumption that all is okay. Most respondents within the age bracket 14-16 years are believed to be active on issues related to breast health and to a greater extent its uptake may be to the closeness to the nurses and matrons in the boarding schools who sensitize students on ways of how to conduct BSE and vitality of breast cancer screening as opposed to students in the same age bracket but coming from the mixed day schools in the rural areas. This can be due to other factors that can be generally be categorized as the institutional factors and proximity which also has a negative association with the uptake of the BSE. Majority pointed out that the distance to the screening facility played an important aspect in terms of whether they would take BSE or not. The greater the distance the higher cost which would not be met by the school going students.

\section{Implication of the study findings}

$45 \%$ of the students interviewed indicated that they had never undertaken any form of breast screening for some reasonable duration, hence the need for more innovative and aggressive ways to improve breast cancer screening uptake among the female students in school. A majority of the respondents $(29.25 \%)$ received information about breast cancer and screening through the radio, hence the need to explore the diversification of radio programmes and advertisements on breast cancer screening to create greater awareness, correct misconceptions and promote breast screening uptake. Forty one point nine percent of the respondents did not undertake breast screening due to long travel distance to screening facilities, hence the need to explore the introduction of mobile screening units to mitigate the influence of long distances to screening facilities on screening uptake.

\section{Conclusions}

The proportion of students in Kisii Sub County that have ever undertaken any form of breast cancer screening in the past is $24.49 \%$. Socio-economic Cultural factors, travel distance to screening facility, cost of screening, most cultural practices and socio-commitments have significant negative correlation with breast cancer screening uptake. However educational level, socio-economic status, most religious practices and socio-cultural factors have a significant positive association with breast cancer screening uptake. Psychosocial variables such as fear, anxiety, stigma and concern for embarrassment were found to be significantly associated to breast cancer screening uptake among the respondents. Institutional characteristics such as Breast Health Education, guidance and follow up by nurses on BSE, Advertisements on breast cancer and screening have significant and positive correlation with breast cancer screening uptake. The level of respondent's knowledge about breast cancer and screening has a significant positive association with breast screening uptake. This study therefore affirms that socio-economic and cultural factors have association with the women's uptake of breast cancer screening. There is association between psychosocial factors and breast screening uptake among female students. There is association between institutional characteristics in $\mathrm{MCH}$ clinics and breast screening uptake. There is association between the student's knowledge about screening and the uptake of breast cancer screening.

\section{Recommendations}

This study makes the following recommendations: The Ministry of Public Health and Sanitation through hospital authorities should diversify Breast health education in schools through the consent from the Ministry of Education to incorporate; more breast health education sessions, guidance by nurses on BSE and regular follow up by nurses to ensure compliance. The Ministry of Public Health and Sanitation in collaboration with the Ministry of Education should intensify advertisements on breast cancer and screening through; radio, internet, television, issue of brochures and posters to bring about increased awareness and an attitude change to promote uptake. The Ministry of Education and that of Public Health should work on a policy framework to disseminate breast cancer screening information to female students at the tertiary level through an integrated curriculum and public forums to counter fear and misconceptions. The Ministry of Health should come up with a breast cancer screening policy to facilitate subsidies of consultation and screening fee and introduce mobile screening units to bring services closer to the students willing and are unable to do uptake breast cancer screening due to proximity so as to improve the students well-being health wise improve uptake.

\section{Suggestions for further research}

1. Study on the factors that influence the adoption of breast health education in middle level colleges

2. Study factors that hinder the formulation and implementation of breast screening education in the secondary school curriculum and to some extent in the tertiary lever colleges.

\section{References}

1. American Cancer Society (2005). How is breast cancer found?

2. McGrath I (2004) The International Network for Cancer Treatment and Research (INCTR); Helping Poorer Nations Confront the Growing Problem. Cancer futures 3: 55-58.

3. Apffelstaedt JP (2006) Cancer Incidents' Report 2000-2002. Nairobi cancer registry. Nairobi.

4. Henry N (2006) The Kenya Breast Health Programme. Early detection saves lives. Nairobi.

5. Muchiri M (2006) Factors Influencing Women Decision for Breast Cance Screening; A case of Ol-kalou Division, Nyandarua District-Kenya. A seminar paper presented in UICC World Congress 2006-Washington, D.C.

6. Anders CK, Hsu DS, Broadwater G, et al. (2008) Young age at diagnosis correlates with worse prognosis and defines a subset of breast cancers with shared patterns of gene expression. J Clinical Oncology 26: 3324-3330.

7. Avci IA (2008). Factors associated with breast self-examination practices and beliefs in female workers at a Muslim community. Eur J OncolNurs 12: 127-133.

8. Giridhara RB, Goleen S, Sharon PC, et al. (2011). Breast cancer screening among females in iran and recommendations for improved practice: a review. Asian Pac J Cancer Prev 12: 1647-1655.

9. American cancer society (2004) Breast cancer Facts and Figures

10. Canbulat N, Uzun $O(2008)$ Health beliefs and breast cancer screening behaviors among female health workers in Turkey. Eur J OncolNurs 12: 148 156

11. Akhtari-Zavare M, Hanafiah JM, Abdul MR, et al. (2011) Knowledge on breast cancer and practice of breast self examination among selected female university students in Malaysia. MHSJ 7: 49-56.

12. Yarbrough SS, Braden CJ (2001) Utility of health belief model as a guide for explaining or predicting breast cancer screening behaviours. J AdvNurs 33: 677-688.

13. Musimbi A (2008). Cancer in Kenya. American J of Clinical Onco.

14. UNAIDS (2004) Global Epidemic Report .Geneva, Switzerland.

15. W.H.O (2007) Schools for Health, Education and Development; A call for Action. W.H.O, Geneva.

16. MOH-Kenya (2005) Second National Health Sector Strategic Plan of Kenya NHSSP II (2005-2010) Draft version. Government press, Nairobi. 